\title{
THE INTERMODAL TRANSPORTATION OF SEMITRAILERS
}

\author{
Václav Cempírek ${ }^{1}$, Bedřich Rathouský2,* , Petr Jirsák²
}

\begin{abstract}
The paper focuses on intermodal transportation systems for semitrailers in Europe. Transportation of semitrailers by rail is a good alternative to direct road transport. In the paper, individual systems are presented and their characteristics are explained. The characteristics of individual transportation systems are the inputs into the WSA and the TOPSIS methods. The results of the methods answers the question which semitrailer transportation system is the most suitable (beneficial) for trucking companies today. The paper may be a source of information for state authorities, trucking companies, intermodal transportation operators and terminal operators.
\end{abstract}

Keywords intermodal transportation, multiple criteria decision making, WSA method, TOPSIS method, standard semitrailer, intermodal semitrailer

\section{INTRODUCTION}

Intermodal transportation is an important measure for sustainable development and - more specifically for sustainable logistics/transport. It is beneficial regarding environmental protection and has potential for modal-shift from road transport to rail (and water) transport. Current situation of modal-split on European freight transport market is: $75.3 \%$ road transport, $18.7 \%$ rail transport and $6 \%$ inland waterway transport (Eurostat, 2020). The data are for the year 2018. The share of transport modes is counted according to transport performance (in tonne-kilometres, $t \mathrm{~km}$ ) There is an effort to use modal-shift tools to improve the modal-split - i.e. to encourage greater use of ecological and safer transport modes (rail and water transport) and decrease the share of road transport. Among hereinbefore mentioned modal-shift tools, the intermodal transportation belong.

Intermodal transportation has two main ranges - accompanied and unaccompanied. Accompanied intermodal transportation systems are transporting whole road vehicles (usually vehicle combinations) and their drivers. Among these systems belong: RO-LA (German: Rollende Landstrasse; Rolling Road), LeShuttle-Freight (operated in Eurotunnel) and ferries. Unaccompanied intermodal transportation systems are transporting only intermodal loading units (ILU; also called intermodal transport units - ITU) like containers (ISO/maritime, ACTS, AWILOG etc.), swap-bodies and semitrailers.

In the intermodal transportation, three types of semitrailers are used - standard (non-cranable), intermodal (cranable) and bimodal. This paper is focused on systems related to road/rail transportation of standard and intermodal semitrailers. Bimodal semitrailers' transportation systems

\footnotetext{
${ }^{1}$ College of Logistics; Palackého 1381/25, 750 02, Přerov, Czech Republic

2 Prague University of Economics and Business, Faculty of Business Administration, Department of logistics, W. Churchill Sq. 4, 130 67, Prague 3, Czech Republic * corresponding author, phone: +420 224098 773, e-mail: Bedrich.Rathousky@vse.cz
} 
are currently not in operation in Europe. Although in the past, the BTZ system (Bayerischer Trailer-Zug) was in operation between Germany and Italy (Barnard, 1995).

Key concepts from the field of intermodal transportation are defined by company UIRR - International Union for Road-Rail Combined Transport (UIRR, 2020), (UIRR, n.d.). As well as in other sources like legislative documents and norms (e.g. ČSN 269375 Terminology of combined transport (1995)) and literature - e.g. Široký et al. (2012), Novák et al. (2013), Rathouský et al. (2016) or Novák et al. (2018). For the purpose of this paper, intermodal transportation is defined as a transportation during which two or more transport modes are used, and a cargo remains in one loading unit (ILU/ITU) during the whole transport process. In the case the longest part of transport process in intermodal transportation is done by rail/water transport (and the first-mile and/or last-mile transport is done by road and is as short as possible), the transportation is called combined transportation.

This paper includes characteristics of available semitrailer transportation systems (in sections 3.2 and 3.3) so it may be used as a source of information for professionals, trucking-companies and state authorities.

The application of Multiple-criteria decision making (MCDM) methods to identify the most suitable system is included (in section 4).

The paper is focused on segment of semitrailers because these days it seems to be the most promising. The share of semitrailers on the intermodal transportation market is continuously growing. According to UIRR Annual Report for the years 2019-2020 the share of semitrailers on intermodal transportation market (regarding transport volume) has been increasing since 2007 and currently is almost 15\% (UIRR, 2020). Despite the "corona-crisis", the number of consignments transported in intermodal semitrailers has grown $4.89 \%$ in 2019. For trucking-companies the operation of standard semitrailers doesn't involve any further (higher) investments into their vehicle-fleet. As well as, higher usage of semitrailers' transportation systems will help to achieve target of moving $30 \%$ of current road cargo transport (with transport distance over $300 \mathrm{~km}$ ) to rail and water transport until 2030 - as stated e.g. in Ministerstvo dopravy (2018) and CargoBeamer (2020a).

\section{METHODOLOGY}

\subsection{Literature review}

The paper is Europe-oriented and it focuses exclusively on currently running systems. The scope of our research (literature review) corresponds with it. The analysed systems are: Modalohr, CargoBeamer, pocket wagons, NiKraSa and ISU. In sections 3.2 and 3.3, the details regarding these systems are presented. All hereinbefore mentioned systems will be considered as variants in the MCDM methods - see section 4 .

Besides studying characteristics of individual semitrailer transportation systems, the researched area (European market) has been analysed from wider environmental point of view - particularly how freight transport negatively influence environment and what are the measures suitable to be taken to mitigate these impacts. Göçmen and Erol (2018) are solving environmental consequences of transport but even considering social factors (accidents and deaths) and risks associated with transportation of dangerous goods. In addition, the problem of non-cranable semitrailers' transportation by rail is often discussed. According to (van Leijen, 2020) and (Bíró, 2019) current share of intermodal semitrailers on European transport market is estimated to ca. 3-10\%. In other words, $90-97 \%$ of all semitrailers are standard (non-cranable). This creates a huge potential for modal-shift from road to rail through implementation of intermodal transportation systems for standard semitrailers. Van Leijen (2020) describes a project for standard semitrailers with potential of moving 50,000 semitrailers on rail (on a route between Netherlands and Poland) in the next 2-3 years. The benefits of modal shift from road to rail 
in countries Austria, Germany, Liechtenstein and Switzerland is solved by UIC (2020). According to den Boer at al. (2011) it is estimated that maximum potential share of rail freight transport is in the range of $31-36 \%$ - i.e. the performance of rail transport can potentially double (compared to the current state).

\subsection{The target of the paper and methods used}

Besides the analysis of semitrailer transportation systems, the target of this paper is to apply MCDM methods WSA (Weighted Sum Approach) and TOPSIS (Technique for Order Preference by Similarity to Ideal Solution) for the selection of the most appropriate system of transportation of semitrailers by rail see section 4. The authors have used two MCDM methods to verify the results. For determination of criteria weightings, the Fuller triangle method has been used. For details regarding chosen methods see section 2.5.

\subsection{Research question and hypothesis}

The paper answers the research question (RQ): "Which semitrailer transportation system to expand throughout Europe to support modal-shift from road to rail?"

Hypothesis: based on the research, the authors expect the most suitable semitrailer transportation system to be one of the horizontal ones - either Modalohr or CargoBeamer.

\subsection{Determining variants and criteria and their weightings}

As mentioned hereinbefore, the systems that will be considered as variants in the MCDM methods will be:

1. Modalohr (LorryRail),

2. CargoBeamer,

3. pocket wagons,

4. NiKraSa,

5. ISU.

The authors decided to use following criteria for evaluation of variants (systems of semitrailer transportation):

1. railway track (siding) electrification possibility,

2. need of investment into intermodal (cranable) semitrailer,

3. number of personnel needed for transhipment in a terminal,

4. the degree of risk of damage to the semitrailer during transhipment,

5. transhipment costs.

Considering hereinbefore specified criteria, it is clear the authors have chosen criteria relevant for "both sides" of intermodal transportation - i.e. the intermodal transportation operators (terminal operators respectively) and trucking companies.

The criterion number 1 has been included to consider possibility of railway track electrification in a terminal. In the case the transhipment is vertical, the electrification of railway track (siding) in a terminal is not possible. In the case the transhipment is horizontal, the electrification is possible. Criterion number 2 represents need of higher investments into intermodal semitrailers for trucking companies. Intermodal semitrailers are more expensive and heavier (ca. 300-500 kilograms) in comparison with standard ones. Criterion number 3 considers the impact on labour costs. The data used in this criterion are obtained from Klemenčič and Burg (2018). Criterion number 4 takes into account potential additional costs (resulting from damage to a semitrailer during transhipment) for trucking companies. In this criterion, the authors considered individual transhipment principles and evaluated the level of risk. 
Criterion number 5 compares individual systems according to transhipment costs (in Euro, excl. VAT) as analysed by Klemenčič and Burg (2018).

The criteria matrix (also called decision matrix) is shown in Tab. 1. This matrix is the input into both methods considered - the WSA and the TOPSIS (see sections 4.1 and 4.2 respectively).

Tab. 1 The criteria matrix; source: Authors.

\begin{tabular}{cccccc}
\hline $\begin{array}{c}\text { Semitrailer } \\
\text { transportation } \\
\text { system }\end{array}$ & $\begin{array}{c}\text { rail } \\
\text { electrification } \\
\text { possibility }\end{array}$ & $\begin{array}{c}\text { investment into } \\
\text { cranable } \\
\text { semitrailer }\end{array}$ & $\begin{array}{c}\text { number of } \\
\text { personnel } \\
\text { needed }\end{array}$ & $\begin{array}{c}\text { potential risk of } \\
\text { damage to } \\
\text { semitrailer }\end{array}$ & $\begin{array}{c}\text { transhipment } \\
\text { costs [€] }\end{array}$ \\
\hline pocket wagons & 0 & 1 & 2 & 1 & 15 \\
NiKraSa & 0 & 0 & 2 & 2 & 15 \\
ISU & 0 & 0 & 3 & 3 & 30 \\
Modalohr & 1 & 0 & 2 & 1 & 80 \\
CargoBeamer & 1 & 0 & 1 & 1 & 75 \\
\hline criterion type & MAX & MIN & MIN & MIN & MIN \\
\hline
\end{tabular}

The values in criterion "rail electrification possibility" have this meaning: if certain system requires vertical transhipment, it means the railway track (siding) can't be electrified - therefore value "zero" means electrification is not possible, value " 1 " means electrification is possible as the particular system belongs to horizontal ones.

Only the first criterion has maximizing character (see the last line in Tab. 1), the values of other criteria will be converted to maximization (see further in section $4.1 \mathrm{Tab} .4$ and $4.2 \mathrm{Tab}$. 10). The principle of conversion of minimization to maximization is described e.g. by Stopka et al. (2019).

The values in criterion "investment into cranable semitrailer" have the same meaning as the first criterion - i.e. "zero" in the case the trucking companies needn't invest into intermodal (cranable) semitrailer, and " 1 " in the case the trucking companies have to invest into intermodal semitrailer.

The values in criterion "number of personnel needed" are self-explaining.

The values in criterion "potential risk of damage to semitrailer" has been determined by authors according to the literature review and the study of characteristics of individual systems. The higher the value of the criterion is, the higher the risk of damage to the semitrailer is.

The values in criterion "transhipment costs" are self-explaining. The values represents the costs (in Euro, excl. VAT) of semitrailer transhipment in a terminal.

As already mentioned above, we will use the Fuller triangle method for determination of criteria weightings - see Fig. 1 .

\begin{tabular}{|l|l|l|l|}
\hline 1 & 1 & 1 & 1 \\
\hline $\mathbf{2}$ & $\mathbf{3}$ & $\mathbf{4}$ & 5 \\
\hline & $\mathbf{2}$ & 2 & $\mathbf{2}$ \\
\hline & 3 & $\mathbf{4}$ & 5 \\
\hline & 3 & 3 \\
\hline & $\mathbf{4}$ & $\mathbf{5}$ \\
\cline { 2 - 3 } & & $\mathbf{4}$ \\
\hline & & 5 \\
\hline
\end{tabular}

Fig. 1 The Fuller triangle; source: Authors. 
The criteria which are more important compared to the others are highlighted with yellow colour and bold font. The application of Fuller triangle method is presented in Tab. 2.

Tab. 2 The preferences and weightings of criteria; source: Authors.

\begin{tabular}{ccc}
\hline Criterion & $\begin{array}{c}\text { Number of } \\
\text { preferences }\end{array}$ & $\begin{array}{c}\text { Weightings } \\
\text { of criteria }\end{array}$ \\
\hline $\mathbf{1}$ & 1 & 0.1 \\
$\mathbf{2}$ & 3 & 0.3 \\
$\mathbf{3}$ & 1 & 0.1 \\
$\mathbf{4}$ & 4 & 0.4 \\
$\mathbf{5}$ & 1 & 0.1 \\
\hline
\end{tabular}

From the results in Tab. 2, it is clear the criteria relevant for trucking companies have significantly higher weightings. This ensures the best suitable system of semitrailer transportation (identified by the MCDM methods) will be "user friendly" for trucking companies.

As the social target is to make modal-shift from road to rail, in the end the trucking companies will be the ones who will make final decision whether to drive door to door "on their own wheels" or whether they will use more ecological and safer intermodal transportation.

\subsection{The MCDM methods}

\subsubsection{The selection of MCDM methods}

The WSA method has been chosen due to the speed of determination of results - and is highly recommended by Stopka et al. (2014). The TOPSIS method (more sophisticated compared to the WSA) is widely used in MCDM problems (it is often mentioned and used in scientific papers) in logistics and transport - e.g. Bottani and Rizzi (2006) are using TOPSIS in the field of outsourcing of logistics services, Perçin, S. (2009) evaluates third party logistics providers, Li et al. (2011) are using TOPSIS for location of a logistics centre - similar to Stopka et al. (2014) who are solving allocation problems of logistics objects, presenting MCDM methods (e.g. ORESTE, TOPSIS, AHP and WSA) as well as methods for determining criteria weightings (e.g. method of ranking, Fuller triangle method and Scoring method). Velasquez and Hester (2013) states that areas of the TOPSIS method application are "supply chain management and logistics, design, engineering and manufacturing systems, business and marketing management, environmental management, human resources management, and water resources management".

The Fuller triangle method has been chosen because for the purpose of this paper, it is possible and sufficient to decide whether one criterion is more important than the other. It is not necessary to use - for instance - Saaty method which is using 9 point scale (Stopka et al., 2014).

Principle of the methods used will not be described here - only the application will be presented (see section 4). The theoretical background of the MCDM methods can be found e.g. in: Chýna et al. (2012) or Spackman et al. (2009).

\subsubsection{Application of MCDM methods}

The general procedure (sequence of steps) in the MCDM process is as follows:

1. identification of variants - in our case: the list of semitrailer transportation systems to be compared (the list of variants is above in section 2.4),

2. identification of criteria - in our case: relevant characteristics of systems considered (the list of criteria and their explanation is above in section 2.4), 
3. determination of criteria weightings - in our case: the application of Fuller triangle method (the results are above in Tab. 2 in section 2.4),

4. application of specific MCDM method - in our case: application of the WSA and the TOPSIS method (see further in sections 4.1 and 4.2 ),

5. interpretation of results - identification of the most suitable variant and discussion (see further in the last paragraphs of sections 4.1 and 4.2 , and the discussion in section 5).

\section{SYSTEMS FOR TRANSPORTATION OF SEMITRAILERS}

As mentioned hereinbefore, there are three types of semitrailers on intermodal transportation market standard semitrailers, intermodal semitrailers and bimodal semitrailers. Each of these types has specific construction defining possibilities of their manipulation (transloading techniques) in intermodal transportation terminals. The type of semitrailer regarding cargo it is designed to transport is irrelevant i.e. it doesn't matter whether the semitrailer is a platform vehicle (with canvas, curtainsider), box-body, refrigerated, tanker, silo etc.

All transportation systems analysed in sections 3.2 and 3.3 allow transportation of semitrailers with height of 4 meters, width of $\mathbf{2 . 6}$ meters and length of $\mathbf{1 3 . 6}$ meters - i.e. if a semitrailer meets requirements for road traffic (given by Directive 2015/719, amending Directive 96/53/ES), it can be transported by rail.

Some types of railway wagons enables transportation of semitrailers with length upto 15 meters - i.e. for example Kögel EuroTrailer.

During rail transport, maximum permissible weight of loaded semitrailer slightly varies according to individual system (type of railway wagon respectively) - it can reach ca. 33-38 tons. Trains usually reach maximum speeds either 100 kmph or 120 kmph.

\subsection{Transloading techniques}

Generally, there are two principles of manipulation with semitrailers - horizontal and vertical. Horizontal systems are usually called Ro-Ro (Roll-on / Roll-off) and vertical systems called Lo-Lo (Lift-on / Lift Off). In the case the Ro-Ro systems are used, it is possible to transload any type of semitrailer - this is, of course, beneficial. The Lo-Lo systems either require intermodal (cranable) semitrailers or usage of specially designed transhipment systems for standard semitrailers. These systems are solved hereinafter.

\subsection{Systems of horizontal transhipment}

\subsubsection{Modalohr (LorryRail)}

Modalohr is a French system for transportation either semitrailers or semitrailer-combinations (including drivers travelling in a couchette wagon coupled in a train). It has been in operation since 2003. The system is universal in its use in unaccompanied and accompanied intermodal transportation. Primarily, it is operated in unaccompanied version.

Central part of Modalohr wagons (loading-deck) is rotary (ca. 45 degrees to the side). The turning process is done via electric motors mounted in the railway track in a terminal. A semitrailer is pulled on a wagon by a tractor (or terminal-tractor) and uncoupled from it. After this, the centre part of a wagon is turned back to the driving position.

The advantage is that each wagon is loaded individually, all the wagons in a train may be loaded simultaneously. The transloading time is very short - the whole train may be loaded with semitrailers in ca. 30-40 minutes (LOHR, 2016a), (LOHR, 2016b). The principle of transhipment in Modalohr system is shown in Fig. 2. 


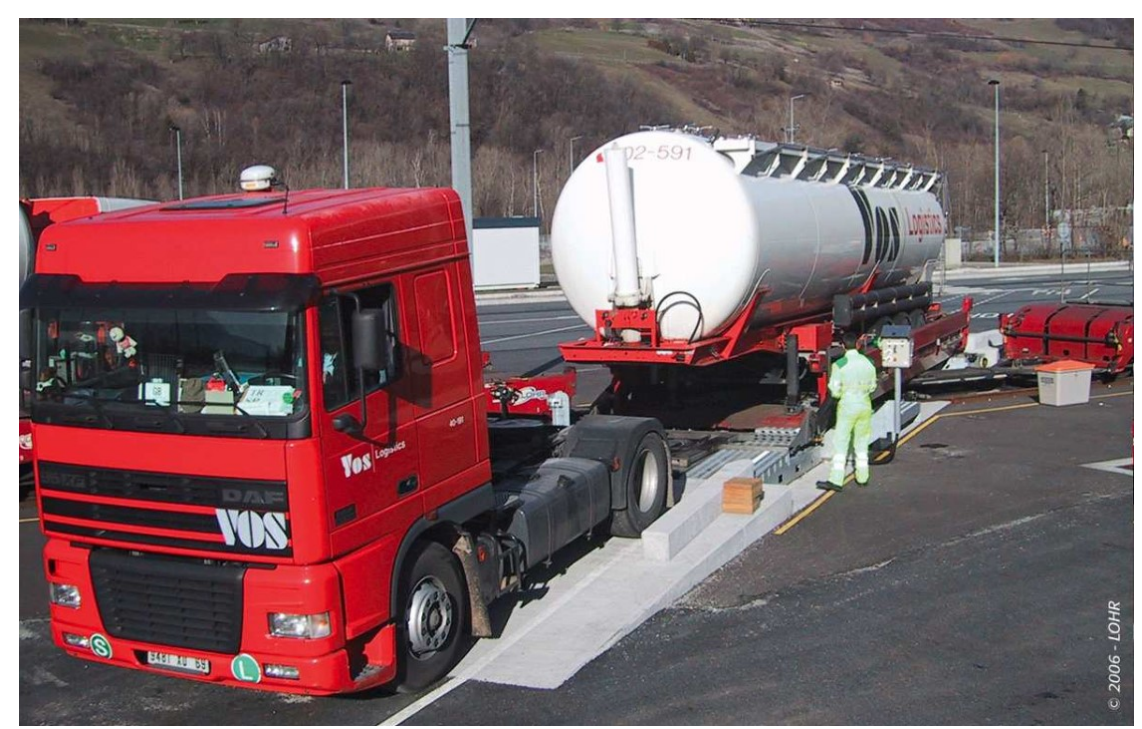

Fig. 2 The Modalohr system - horizontal transhipment of standard semitrailer; source: LOHR.

Currently, these are the lines of Modalohr system (VIIA, n.d.):

1. Aiton (F) - Orbassano (I),

2. Bettembourg (L) - Le Boulou (F),

3. Calais (F) - Le Boulou (F),

4. Calais (F) - Orbassano (I),

5. Séte (F) - Paris (F) - Zeebrugge (B),

6. Barcelona (E) - Bettembourg (L),

7. Macon (F) - Calais (F),

8. Macon (F) - Le Boulou (F).

On the line Barcelona-Bettembourg, it is estimated to save over 22,000 trucks/year on the road, representing a reduction in $\mathbf{C O}_{2}$ emissions of 23,070 tonnes/year (Todd, 2019).

\subsubsection{CargoBeamer}

The project originally started in 1998. The pilot project took place in Leipzig (D) - a terminal for three CargoBeamer wagons has been built. First tests of CargoBeamer system were on the route between Spain and Germany - semitrailers have been loaded with cargo for automotive industry (Volkswagen AG). Since 2015, the line between Kaldenkirchen (D) and Domodossola (I) has been in operation. Since opening, more than 70,000 semitrailers has been moved from road to rail (CargoBeamer, 2020b).

On May 14th 2020, new line connecting Kaldenkirchen (D) and Sestokai (LT) has been opened. The target is to implement CargoBeamer system in its horizontal transhipment form (for explanation see the next paragraph). But if necessary (due to lack of special transloading equipment in a terminal), vertical transhipment of semitrailers is possible. The principle of standard semitrailers' transhipment is then the same as in the case of NiKraSa system (see further in section 3.3.2), or direct vertical transhipment of intermodal semitrailers takes place.

For horizontal transhipment of a semitrailer onto CargoBeamer wagon, the detachable central part (loading platform, also called a "pallet") of a wagon is positioned radially next to a wagon. On the platform a semitrailer is pulled by a tractor (or a terminal tractor) and dropped there. Then the platform is moved 
back onto a wagon. The loading process of the whole train takes 15-20 minutes (CargoBeamer, 2020c). The transhipment process in CargoBeamer is shown in Fig. 3.

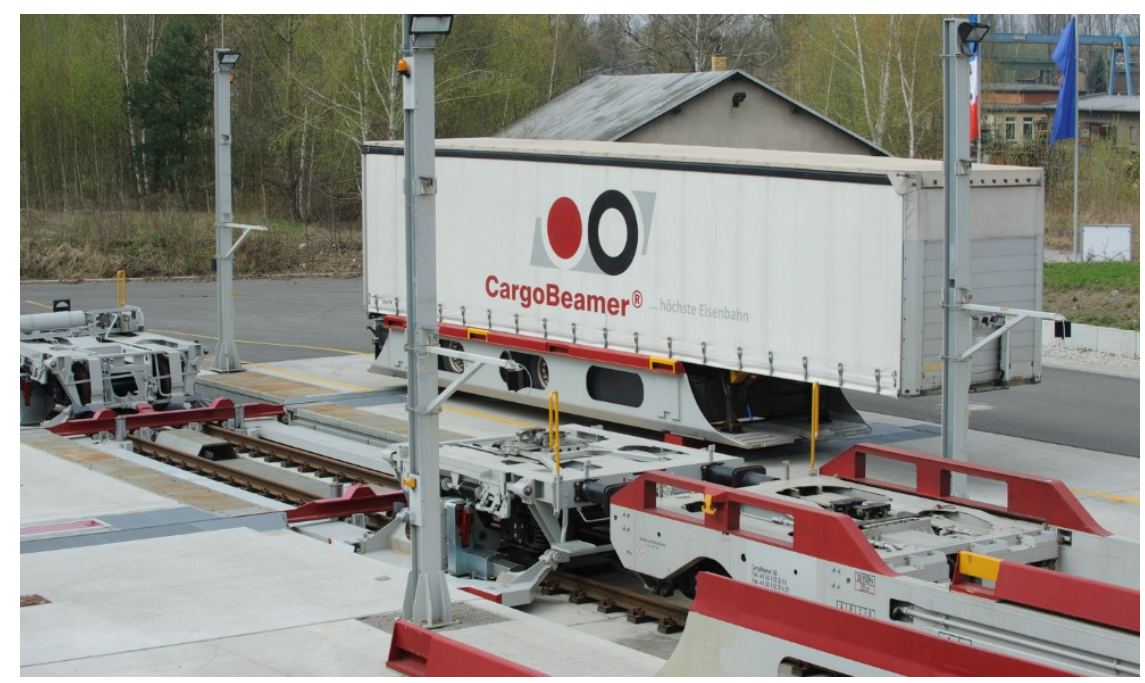

Fig. 3 The CargoBeamer system - horizontal transhipment of standard semitrailer; source: CargoBeamer.

According to CargoBeamer (2020b), a new terminal is under construction in Calais (F). The terminal will be able to unload and load trains with up to 36 semitrailers, in a fully automated process within 20 minutes. The opening of the Calais terminal is scheduled for spring 2021. Routes from Calais to Great Britain (via Eurotunnel and ferries) are planned.

CargoBeamer system enables very quick transhipment of semitrailers between two trains, as well. This is beneficial primarily in terminals situated at the area where different rail-gauges meet (typically "normal" and "wide"). It is relevant at France-Spain border, Slovakia-Ukraine border etc. Complete transloading process between two trains takes ca. 1 hour, compared to 2-3 days "standard practice" when vertical transhipment is used (CargoBeamer, 2010). CargoBeamer system eliminates competitive disadvantage for rail transport compared with road transport.

\subsection{Systems of vertical transhipment}

\subsubsection{Pocket wagons}

System of pocket wagons is still the most important system in unaccompanied intermodal transportation. Pocket wagons are suitable for transportation of semitrailers, swap-bodies and ISO (maritime) containers - i.e. they are highly universal. Unfortunately, transloading of hereinbefore named ILUs is always vertical. In perspective of this paper, solving transportation of semitrailers, it is a disadvantage for trucking companies as they need to invest into specially designed intermodal (cranable) semitrailers. Intermodal semitrailers are (in comparison with standard ones) more expensive and ca. 300500 kilograms heavier - i.e. have lower payload. The other possibility is use of NiKraSa or ISU systems, developed for vertical transhipment of standard semitrailers (details are further in 3.3.2 and 3.3.3).

The transhipment of semitrailers onto wagons is usually done vertically by reach-stackers or gantry cranes (depends on size of a terminal and thus on its equipment). The principle of transhipment (using a gantry crane) is shown in Fig. 4. In the figure, the yellow rectangles on semitrailers are shown. On intermodal (cranable) semitrailers they mark places at which a gantry crane or a reach-stacker can grab the semitrailer and lift it. 


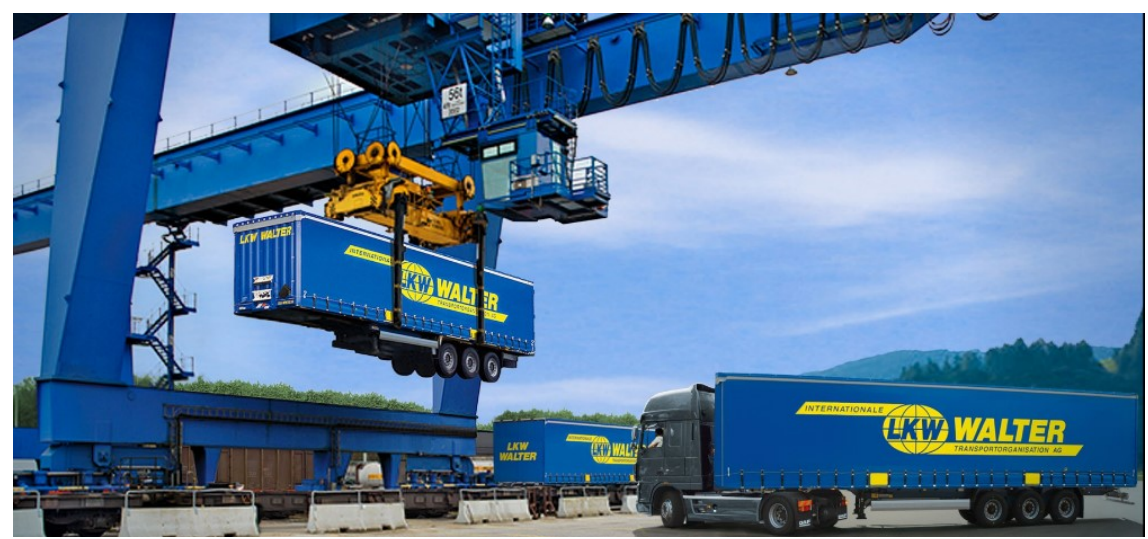

Fig. 4 The system of pocket wagons - vertical transhipment of intermodal semitrailer; source: LKW WALTER.

The necessity of vertical transloading brings a disadvantage related to railway traffic as well. The railway track (railway siding) can't be electrified. Transloading procedure in a terminal takes 2-3 hours, depending especially on the length of a train (number of ILUs transloaded) and on type and number of transloading equipment in a terminal.

\subsubsection{NiKraSa}

The name comes from German "Nicht-kranbare Sattelauflieger" - i.e. "non-cranable semitrailer" in English. The system enables vertical transhipment of standard (non-cranable) semitrailers using special platform - a type of trough, similar to the "pallet" used in CargoBeamer system (see section 3.2.2). The whole principle of NiKraSa system is similar to CargoBeamer system but with the difference that transloading of the platform with semitrailer is always vertical - see Fig. 5.

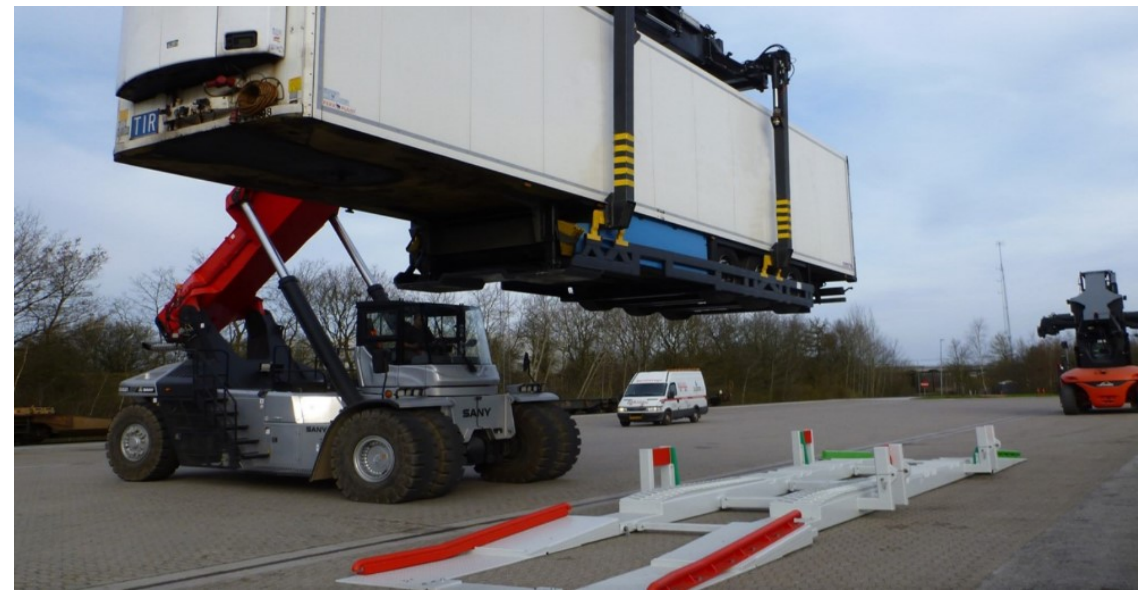

Fig. 5 The NiKraSa system - vertical transhipment of standard semitrailer; source: LKW WALTER.

The platform is positioned next to a train on terminal handling area by a reach-stacker or a gantry crane. Next, a semitrailer is pulled onto the platform using a tractor or a terminal-tractor. The last step is vertical transhipment of the platform with semitrailer into the railway wagon (Nagel-Group, n.d.), (IRJ, 2018). The system was officially launched in 2014.

Currently these lines are running (TX Logistik, n.d.), (Klemenčič and Burg, 2018):

1. Padborg (DK) - Verona (I),

2. Herne (D) - Verona (I), 
3. Herne (D) - Budapest (H),

4. Bettembourg (L) - Trieste (I),

5. Lübeck (D) - Verona (I),

6. Herne (D) - Lübeck (D).

NiKraSa system is using standard pocket wagons (e.g. type Sdggmrss) and it doesn't involve any additional investments into terminals infrastructure. The utilization of terminals can even be improved implementing NiKraSa system. On the other hand, positioning a semitrailer onto the platform brings potential risk of damage to the semitrailer (Cempírek, 2018).

\subsubsection{ISU}

The name comes from German "Innovativer Sattelauflieger Umschlag" - i.e. "Innovative semitrailer transhipment". History of the system goes back to the year 2006. The principle of ISU is based on special ramp which is placed in a terminal - and on which a semitrailer is towed by a tractor (or a terminaltractor). Then, a semitrailer is uncoupled from a tractor. Chain hinges (or textile-straps) are connected to semitrailer's king-pin (via traverse) and to $1^{\text {st }}$ and $3^{\text {rd }}$ axle (via wheel-grippers). Vertical transhipment into a wagon is then done via reach-stacker or gantry-crane (Hafner, 2019), (Possegger, 2012). Potential risk of damage to semitrailer structure (mainly to axle aggregate and tyres during lifting) is disadvantage of ISU system. Fig. 6 shows positioning of chain hinges at the semitrailer's kingpin and axles (on the left) and vertical transhipment into a railway wagon (on the right).
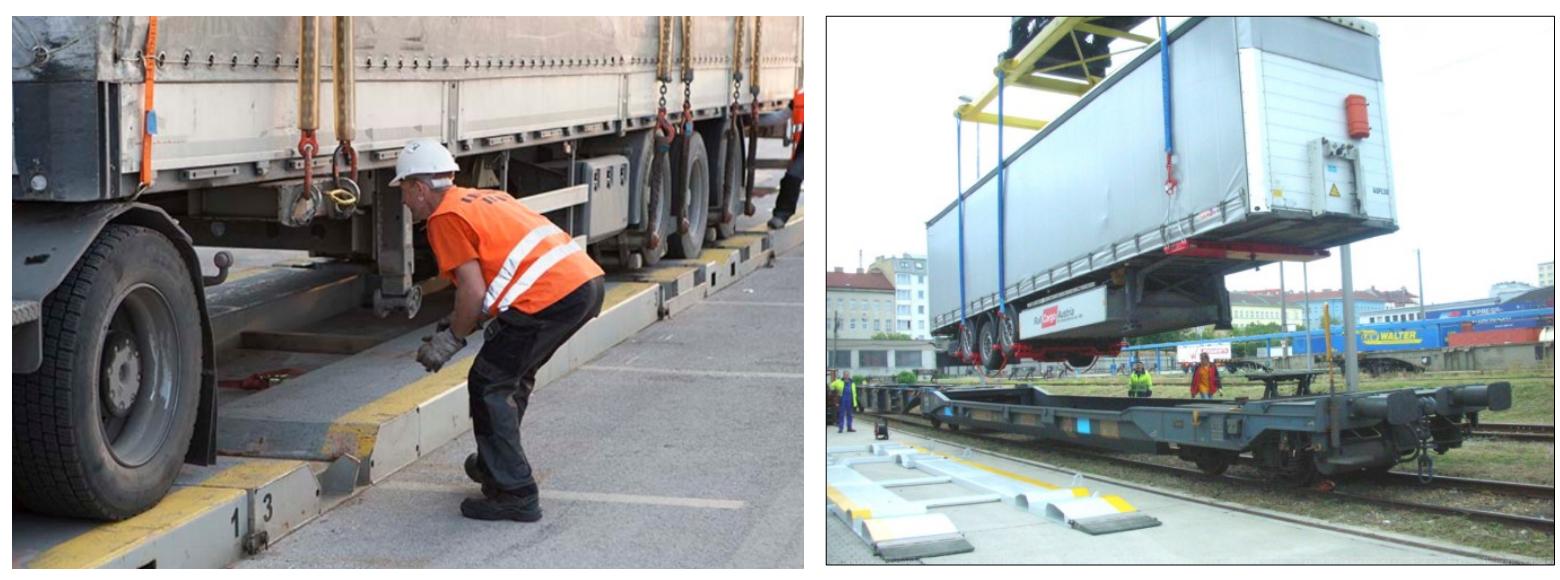

Fig. 6 The ISU system - positioning of chain hinges (left) and vertical transhipment of standard semitrailer (right); source: Intermodale24-rail; Bravo-project.

Pilot routes of ISU system were between Wels (A) and Istanbul (TR) and between Wels (A) and Stara Zagora (RO) - opened in 2009 and 2010 respectively. Deiterding et al. (2012) says that commercial demonstration is running between Wels (A) and Curtici (RO) since 2010. According to Hafner (2019), the line between Wels (A) and Trieste (I) is in the run, as well.

\section{APPLICATION OF THE MCDM TO IDENTIFY THE MOST SUITABLE SEMITRAILER TRANSPORTATION SYSTEM}

In this section we will present individual steps of the WSA and the TOPSIS methods and determine their results. The comparison of results of both methods and the discussion is presented further in section 5. 


\subsection{The WSA method}

Individual matrixes, corresponding with individual steps, of the WSA method are presented in Tab. $\mathbf{3}$ to Tab. 8.

Tab. 3 The criteria matrix; source: Authors.

\begin{tabular}{cccccc}
\hline $\begin{array}{c}\text { Semitrailer } \\
\text { transportation } \\
\text { system }\end{array}$ & $\begin{array}{c}\text { rail } \\
\text { electrification } \\
\text { possibility }\end{array}$ & $\begin{array}{c}\text { investment into } \\
\text { cranable } \\
\text { semitrailer }\end{array}$ & $\begin{array}{c}\text { number of } \\
\text { personnel } \\
\text { needed }\end{array}$ & $\begin{array}{c}\text { potential risk of } \\
\text { damage to } \\
\text { semitrailer }\end{array}$ & $\begin{array}{c}\text { transhipment } \\
\text { costs [€] }\end{array}$ \\
\hline pocket wagons & 0 & 1 & 2 & 1 & 15 \\
NiKraSa & 0 & 0 & 2 & 2 & 15 \\
ISU & 0 & 0 & 3 & 3 & 30 \\
Modalohr & 1 & 0 & 2 & 1 & 80 \\
CargoBeamer & 1 & 0 & 1 & 1 & 75 \\
\hline criterion type & MAX & MIN & MIN & MIN & MIN \\
\hline
\end{tabular}

Tab. 4 The matrix of conversion of minimization values to maximization values; source: Authors.

\begin{tabular}{cccccc}
\hline $\begin{array}{c}\text { Semitrailer } \\
\text { transportation } \\
\text { system }\end{array}$ & $\begin{array}{c}\text { rail } \\
\text { electrification } \\
\text { possibility }\end{array}$ & $\begin{array}{c}\text { investment into } \\
\text { cranable } \\
\text { semitrailer }\end{array}$ & $\begin{array}{c}\text { number of } \\
\text { personnel } \\
\text { needed }\end{array}$ & $\begin{array}{c}\text { potential risk of } \\
\text { damage to } \\
\text { semitrailer }\end{array}$ & $\begin{array}{c}\text { transhipment } \\
\text { costs [€] }\end{array}$ \\
\hline pocket wagons & 0 & 0 & 1 & 2 & 65 \\
NiKraSa & 0 & 1 & 1 & 1 & 65 \\
ISU & 0 & 1 & 0 & 0 & 50 \\
Modalohr & 1 & 1 & 1 & 2 & 0 \\
CargoBeamer & 1 & 1 & 2 & 2 & 5 \\
\hline criterion type & MAX & MAX & MAX & MAX & MAX \\
\hline
\end{tabular}

Tab. 5 The matrix of ideal and basal variants; source: Authors.

\begin{tabular}{cccccc}
\hline & $\begin{array}{c}\text { rail } \\
\text { electrification } \\
\text { possibility }\end{array}$ & $\begin{array}{c}\text { investment into } \\
\text { cranable } \\
\text { semitrailer }\end{array}$ & $\begin{array}{c}\text { number of } \\
\text { personnel } \\
\text { needed }\end{array}$ & $\begin{array}{c}\text { potential risk of } \\
\text { damage to } \\
\text { semitrailer }\end{array}$ & $\begin{array}{c}\text { transhipment } \\
\text { costs [€] }\end{array}$ \\
\hline ideal variant & 1 & 1 & 2 & 2 & 65 \\
basal variant & 0 & 0 & 0 & 0 & 0 \\
\hline
\end{tabular}

Tab. 6 The normalized criterion matrix; source: Authors.

\begin{tabular}{cccccc}
\hline $\begin{array}{c}\text { Semitrailer } \\
\text { transportation } \\
\text { system }\end{array}$ & $\begin{array}{c}\text { rail } \\
\text { electrification } \\
\text { possibility }\end{array}$ & $\begin{array}{c}\text { investment into } \\
\text { cranable } \\
\text { semitrailer }\end{array}$ & $\begin{array}{c}\text { number of } \\
\text { personnel } \\
\text { needed }\end{array}$ & $\begin{array}{c}\text { potential risk of } \\
\text { damage to } \\
\text { semitrailer }\end{array}$ & $\begin{array}{c}\text { transhipment } \\
\text { costs [€] }\end{array}$ \\
\hline pocket wagons & 0 & 0 & 0.50 & 1.00 & 1.00 \\
NiKraSa & 0 & 1.00 & 0.50 & 0.50 & 1.00 \\
ISU & 0 & 1.00 & 0 & 0 & 0.77 \\
Modalohr & 1.00 & 1.00 & 0.50 & 1.00 & 0 \\
CargoBeamer & 1.00 & 1.00 & 1.00 & 1.00 & 0.08 \\
\hline
\end{tabular}


Tab. 7 The matrix of criteria weightings; source: Authors.

\begin{tabular}{cccccc}
\hline & $\begin{array}{c}\text { rail } \\
\text { electrification } \\
\text { possibility }\end{array}$ & $\begin{array}{c}\text { investment into } \\
\text { cranable } \\
\text { semitrailer }\end{array}$ & $\begin{array}{c}\text { number of } \\
\text { personnel } \\
\text { needed }\end{array}$ & $\begin{array}{c}\text { potential risk of } \\
\text { damage to } \\
\text { semitrailer }\end{array}$ & $\begin{array}{c}\text { transhipment } \\
\text { costs [€] }\end{array}$ \\
\hline $\begin{array}{c}\text { criteria } \\
\text { weightings }\end{array}$ & 0.1 & 0.3 & 0.1 & 0.4 & 0.1 \\
\hline
\end{tabular}

Tab. 8 The aggregate utility and ranking of variants; source: Authors.

\begin{tabular}{ccc}
\hline $\begin{array}{c}\text { Semitrailer } \\
\text { transportation } \\
\text { system }\end{array}$ & $\begin{array}{c}\text { the utility } \\
\text { of individual } \\
\text { variants }\end{array}$ & $\begin{array}{c}\text { the rank } \\
\text { of } \\
\text { variants }\end{array}$ \\
\hline pocket wagons & 0.55 & 4 \\
NiKraSa & 0.65 & 3 \\
ISU & 0.38 & 5 \\
Modalohr & 0.85 & 2 \\
CargoBeamer & 0.91 & 1 \\
\hline
\end{tabular}

The result: according to the WSA method, the best suitable system is CargoBeamer. The resulting aggregate utility of this variant is $\mathbf{0 . 9 1}$.

\subsection{The TOPSIS method}

Individual matrixes, corresponding with individual steps, of the TOPSIS method are presented in Tab. 9 to Tab. 16.

Tab. 9 The criterion matrix; source: Authors.

\begin{tabular}{cccccc}
\hline $\begin{array}{c}\text { Semitrailer } \\
\text { transportation } \\
\text { system }\end{array}$ & $\begin{array}{c}\text { rail } \\
\text { electrification } \\
\text { possibility }\end{array}$ & $\begin{array}{c}\text { investment into } \\
\text { cranable } \\
\text { semitrailer }\end{array}$ & $\begin{array}{c}\text { number of } \\
\text { personnel } \\
\text { needed }\end{array}$ & $\begin{array}{c}\text { potential risk of } \\
\text { damage to } \\
\text { semitrailer }\end{array}$ & $\begin{array}{c}\text { transhipment } \\
\text { costs [€] }\end{array}$ \\
\hline pocket wagons & 0 & 1 & 2 & 1 & 15 \\
NiKraSa & 0 & 0 & 2 & 2 & 15 \\
ISU & 0 & 0 & 3 & 3 & 30 \\
Modalohr & 1 & 0 & 2 & 1 & 80 \\
CargoBeamer & 1 & 0 & 1 & 1 & 75 \\
\hline criterion type & MAX & MIN & MIN & MIN & MIN \\
\hline
\end{tabular}

Tab. 10 The matrix of conversion of minimization values to maximization values; source: Authors.

\begin{tabular}{cccccc}
\hline $\begin{array}{c}\text { Semitrailer } \\
\text { transportation } \\
\text { system }\end{array}$ & $\begin{array}{c}\text { rail } \\
\text { electrification } \\
\text { possibility }\end{array}$ & $\begin{array}{c}\text { investment into } \\
\text { cranable } \\
\text { semitrailer }\end{array}$ & $\begin{array}{c}\text { number of } \\
\text { personnel } \\
\text { needed }\end{array}$ & $\begin{array}{c}\text { potential risk of } \\
\text { damage to } \\
\text { semitrailer }\end{array}$ & $\begin{array}{c}\text { transhipment } \\
\text { costs [ } € \text { ] }\end{array}$ \\
\hline pocket wagons & 0 & 0 & 1 & 2 & 65 \\
NiKraSa & 0 & 1 & 1 & 1 & 65 \\
ISU & 0 & 1 & 0 & 0 & 50 \\
Modalohr & 1 & 1 & 1 & 2 & 0 \\
CargoBeamer & 1 & 1 & 2 & 2 & 5 \\
\hline criterion type & $\mathrm{MAX}$ & $\mathrm{MAX}$ & $\mathrm{MAX}$ & $\mathrm{MAX}$ & $\mathrm{MAX}$ \\
\hline
\end{tabular}


Tab. 11 The normalized criterion matrix; source: Authors.

\begin{tabular}{cccccc}
\hline $\begin{array}{c}\text { Semitrailer } \\
\text { transportation } \\
\text { system }\end{array}$ & $\begin{array}{c}\text { rail } \\
\text { electrification } \\
\text { possibility }\end{array}$ & $\begin{array}{c}\text { investment into } \\
\text { cranable } \\
\text { semitrailer }\end{array}$ & $\begin{array}{c}\text { number of } \\
\text { personnel } \\
\text { needed }\end{array}$ & $\begin{array}{c}\text { potential risk of } \\
\text { damage to } \\
\text { semitrailer }\end{array}$ & $\begin{array}{c}\text { transhipment } \\
\text { costs [€] }\end{array}$ \\
\hline pocket wagons & 0 & 0 & 0.1429 & 0.1538 & 0.0059 \\
NiKraSa & 0 & 0.2500 & 0.1429 & 0.0769 & 0.0059 \\
ISU & 0 & 0.2500 & 0 & 0 & 0.0046 \\
Modalohr & 0.5000 & 0.2500 & 0.1429 & 0.1538 & 0 \\
CargoBeamer & 0.5000 & 0.2500 & 0.2857 & 0.1538 & 0.0005 \\
\hline
\end{tabular}

Tab. 12 The matrix of criteria weightings; source: Authors.

\begin{tabular}{cccccc}
\hline & $\begin{array}{c}\text { rail } \\
\text { electrification } \\
\text { possibility }\end{array}$ & $\begin{array}{c}\text { investment into } \\
\text { cranable } \\
\text { semitrailer }\end{array}$ & $\begin{array}{c}\text { number of } \\
\text { personnel } \\
\text { needed }\end{array}$ & $\begin{array}{c}\text { potential risk of } \\
\text { damage to } \\
\text { semitrailer }\end{array}$ & $\begin{array}{c}\text { transhipment } \\
\text { costs [€] }\end{array}$ \\
\hline $\begin{array}{c}\text { criteria } \\
\text { weightings }\end{array}$ & 0.1 & 0.3 & 0.1 & 0.4 & 0.1 \\
\hline
\end{tabular}

Tab. 13 The weighted criteria matrix; source: Authors.

\begin{tabular}{cccccc}
\hline $\begin{array}{c}\text { Semitrailer } \\
\text { transportation } \\
\text { system }\end{array}$ & $\begin{array}{c}\text { rail } \\
\text { electrification } \\
\text { possibility }\end{array}$ & $\begin{array}{c}\text { investment into } \\
\text { cranable } \\
\text { semitrailer }\end{array}$ & $\begin{array}{c}\text { number of } \\
\text { personnel } \\
\text { needed }\end{array}$ & $\begin{array}{c}\text { potential risk of } \\
\text { damage to } \\
\text { semitrailer }\end{array}$ & $\begin{array}{c}\text { transhipment } \\
\text { costs [€] }\end{array}$ \\
\hline pocket wagons & 0 & 0 & 0.0143 & 0.0615 & 0.0006 \\
NiKraSa & 0 & 0.0750 & 0.0143 & 0.0308 & 0.0006 \\
ISU & 0 & 0.0750 & 0 & 0 & 0.0005 \\
Modalohr & 0.0500 & 0.0750 & 0.0143 & 0.0615 & 0 \\
CargoBeamer & 0.0500 & 0.0750 & 0.0286 & 0.0615 & 0 \\
\hline
\end{tabular}

Tab. 14 The matrix of ideal and basal variants; source: Authors.

\begin{tabular}{cccccc}
\hline & $\begin{array}{c}\text { rail } \\
\text { electrification } \\
\text { possibility }\end{array}$ & $\begin{array}{c}\text { investment into } \\
\text { cranable } \\
\text { semitrailer }\end{array}$ & $\begin{array}{c}\text { number of } \\
\text { personnel } \\
\text { needed }\end{array}$ & $\begin{array}{c}\text { potential risk of } \\
\text { damage to } \\
\text { semitrailer }\end{array}$ & $\begin{array}{c}\text { transhipment } \\
\text { costs [€] }\end{array}$ \\
\hline $\mathbf{H}_{\mathbf{j}}$ & 0.0500 & 0.0750 & 0.0286 & 0.0615 & 0.0006 \\
$\mathbf{D}_{\mathbf{j}}$ & 0 & 0 & 0 & 0 & 0 \\
\hline
\end{tabular}

Tab. 15 The matrix of distances from ideal and basal variants; source: Authors.

\begin{tabular}{ccc}
\hline $\begin{array}{c}\text { Semitrailer } \\
\text { transportation } \\
\text { system }\end{array}$ & $\begin{array}{c}\text { distance } \\
\text { from } \\
\text { ideal variant }\end{array}$ & $\begin{array}{c}\text { distance } \\
\text { from } \\
\text { basal variant }\end{array}$ \\
\hline pocket wagons & 0.0913 & 0.0632 \\
NiKraSa & 0.0604 & 0.0823 \\
ISU & 0.0843 & 0.0750 \\
Modalohr & 0.0143 & 0.1101 \\
CargoBeamer & 0.0005 & 0.1128 \\
\hline
\end{tabular}


Tab. 16 The indicators of relative distance from basal variant and ranking; source: Authors.

\begin{tabular}{ccc}
\hline $\begin{array}{c}\text { Semitrailer } \\
\text { transportation } \\
\text { system }\end{array}$ & $\begin{array}{c}\text { the indicator of } \\
\text { relative } \\
\text { distance from } \\
\text { basal variant }\end{array}$ & $\begin{array}{c}\text { the rank } \\
\text { of variants }\end{array}$ \\
\hline pocket wagons & 0.41 & 5 \\
NiKraSa & 0.58 & 3 \\
ISU & 0.47 & 4 \\
Modalohr & 0.89 & 2 \\
CargoBeamer & 1.00 & 1 \\
\hline
\end{tabular}

The result: according to the TOPSIS method, the best suitable system is CargoBeamer. Its value of indicator of relative distance from basal variant is $\mathbf{1 . 0 0}$ (when considering three decimal numbers: $\mathbf{0 . 9 9 5}$ ).

\section{FINDINGS AND DISCUSSION}

The authors demonstrated application of MCDM methods on determination of the best suitable semitrailer transportation system in Europe. According to results of both the WSA method and the TOPSIS method, the best suitable system of semitrailer transportation is the CargoBeamer. The CargoBeamer belongs to horizontal transhipment systems - i.e. it is perfectly suitable for trucking companies operating standard (non-cranable) semitrailers. The vast majority of trucking companies operate this type of semitrailers. At best, only $10 \%$ of semitrailers are intermodal (cranable) - i.e. enable vertical transhipment in intermodal transportation terminals.

The Modalohr system is the second best according to both methods. It has reached 0.85 (in the WSA method) and 0.89 (in the TOPSIS method). Similar to CargoBeamer, the good rank is caused by the criteria weightings. The system NiKraSa has reached the third place - again in both methods: 0.65 in the WSA method and 0.58 in the TOPSIS method. The last two systems (ISU and pocket wagons) have different positions. According to the WSA method, the fourth place has the system of pocket wagons and the fifth place has the ISU system - according to the TOPSIS method, the rank is vice versa.

In general, the implementation of horizontal transhipment systems for semitrailers will have positive impact on modal-split. Currently, the share of road transport on European transportation market is $75.3 \%$, the share of rail transport is only $18.7 \%$. But, potentially, the rail transport could reach the share of 31-36\% (den Boer at al., 2011). At least part of this increase could be due to (thanks to) higher performance of intermodal transportation.

In this paper, the authors have been primarily oriented on suitability of individual systems for trucking companies. If the authors would have chosen different criteria and/or counted different weightings of the same criteria, the results could be different. In the next survey, different criteria and their weightings can be used. We can primarily consider these cost-related criteria and technical criteria as:

1. the investment costs into terminals (regarding their location, size and particular system(s) operated),

2. the investment/lease costs into railway wagons designed for individual systems,

3. the capacities of trains used in individual systems (number of ILUs they can transport),

4. the degree of versatility of railway wagons used (regarding transportation possibilities of different types of ILUs).

By implementing hereinbefore mentioned criteria into MCDM methods we will increase the objectivity of choice of the best suitable semitrailer transportation system. 


\section{CONCLUSIONS}

The objective of this research study was to introduce functional systems of transportation of semitrailers by rail. After the necessary description of individual systems, the application of MCDM methods (the WSA and the TOPSIS) took place. The authors have analysed individual semitrailer transportation systems and their characteristics regarding:

1. their technology: possibility of railway-track electrification, number of terminal-personnel needed and transhipment costs,

2. suitability for trucking-companies: need of investment into intermodal semitrailer and risks of damage to a semitrailer during transhipment.

The paper provides results of MCDM methods. The results are presented in section 4 and gave the answer on the research question defined in section 2.3 - the most suitable system is horizontal transhipment system CargoBeamer. The WSA method gave result of 0.91 and the TOPSIS method 1.00 .

The hypothesis specified in section 2.3 has been confirmed - the system identified as the most suitable belongs to horizontal ones.

Corresponding with the discussion in section 5, further research should include the survey among representatives of trucking-companies, intermodal transportation operators, terminal operators and authorities, to identify their needs, possibilities and expectations towards intermodal transportation. The discussion over criteria, their values and their importance should take place, as well.

\section{References}

Barnard, B. 1995. RoadRailer Trailer to Make European Intermodal Debut. Available at: https://www.joc.com/roadrailer-trailer-make-european-intermodal-debut 19950517.html [Accessed: 2020, October 12].

Bíró, K.A. 2019. Combined Transport - Future Ante Portas. Available at: http://innorail2019.hu/wpcontent/uploads/2019/12/Kopp\%C3\%A1ny-Ajtony-B\%C3\%8DR\%C3\%93 Combined-transport\%E2\%80\%93-a-solution-to-optimise-the-transport-subsectors-and-to-improve-the-competitiveness-ofthe-customers.pdf [Accessed: 2020, October 14].

Bottani, E. and Rizzi, A. 2006. A fuzzy TOPSIS methodology to support outsourcing of logistics services. Supply Chain Management, 11(4), pp. 294-308. Available at:

https://doi.org/10.1108/13598540610671743 [Accessed: 2020, October 25].

CargoBeamer. 2010. CargoBeamer teaching trucks to use the railways. Available at: https://www.youtube.com/watch?v=49gD5F3mn1U [Accessed: 2020, October 18].

CargoBeamer. 2020a. LG Cargo, PKP Cargo und CargoBeamer realisieren ersten Pilot-Zug für StandardSattelauflieger auf der Rail Baltica. Available at: https://www.cargobeamer.eu/LG-Cargo-PKP-Cargo-andCargoBeamer-team-up-to-pilot-semi-trailers-train-853035.html [Accessed: 2020, October 18].

CargoBeamer. 2020b. Groundbreaking for CargoBeamers first own multi-modal terminal in Calais. Available at: https://www.cargobeamer.eu/Groundbreaking-for-CargoBeamers-first-own-multi-modalterminal-in-Calais-853090.html [Accessed: 2020, October 18].

CargoBeamer. 2020c. How it works in a CargoBeamer Terminal! Available at: https://www.cargobeamer.eu/How-it-works-849768.html [Accessed: 2020, October 18].

Cempírek, V. 2018. Výhody a nevýhody intermodálního systému Nikrasa. Logistika, 25(1-2), pp. 40-41.

Český normalizační institut. 1995. [In Czech: Terminologie kombinované dopravy]. ČSN 26 9375. Praha: ČNI. 
Chýna, V., Kuncová, M. and Sekničková, J. 2012. Estimation of weights in multi-criteria decision-making optimization models. In Proceedings of 30th International Conference Mathematical Methods in Economics 2012. Karviná, September 11-13. Opava, Czech Republic: Silesian University in Opava, pp. 355-360.

Deiterding, L., Galonske, N. and Karcher, S. 2012. CREAM "Customer-driven Rail-freight Services on a European Mega-corridor based on Advanced business and Operating Models". Available at: https://www.researchgate.net/publication/271609689 CREAM Customer-driven Rail-

freight Services on a European Mega-corridor based on Advanced business and Operating Models [Accessed: 2020, October 24].

den Boer, E., van Essen, H., Brouwer, F., Pastori, E. and Moizo, A. 2011. Potential of modal shift to rail transport - study on the projected effects on GHG emissions and transport volumes. Available at: https://uic.org/IMG/pdf/study on modal shift final-2.pdf [Accessed: 2020, October 16].

European Communities. 1996. COUNCIL DIRECTIVE 96/53/EC of 25 July 1996 laying down for certain road vehicles circulating within the Community the maximum authorized dimensions in national and international traffic and the maximum authorized weights in international traffic. In: EUR-Lex. Available at: https://eur-lex.europa.eu/legal-content/EN/TXT/PDF/?uri=CELEX:31996L0053\&from=en.

European Union. 2015. DIRECTIVE (EU) 2015/719 OF THE EUROPEAN PARLIAMENT AND OF THE COUNCIL of 29 April 2015 amending Council Directive 96/53/EC laying down for certain road vehicles circulating within the Community the maximum authorised dimensions in national and international traffic and the maximum authorised weights in international traffic. In: EUR-Lex. Available at: https://eurlex.europa.eu/legal-content/EN/TXT/PDF/?uri=CELEX:32015L0719\&from=en.

Eurostat. (C) 2020. Freight transport statistics - modal split. [Online]. Available at: https://ec.europa.eu/eurostat/statistics-explained/index.php/Freight transport statistics modal split\#Modal split in the EU [Accessed: 2020, October 12].

Göçmen, E. and Erol, R. 2018. The Problem of Sustainable Intermodal Transportation: A Case Study of an International Logistics Company, Turkey. Sustainability 2018, 10(11), 4268. [Online]. Available at: https://doi.org/10.3390/su10114268 [Accessed: 2020, October 25].

Hafner, B. 2019. Lorry chassis piggybacking on the railway lines. Available at: https://blog.railcargo.com/en/artikel/lkw-chassis-huckepack-auf-schiene [Accessed: 2020, October 19].

IRJ. 2018. Intermodal innovation gets non-cranable trailers on trains. Available at: https://www.railjournal.com/freight/intermodal-innovation-gets-non-cranable-trailers-on-trains/ [Accessed: 2020, October 19].

Klemenčič, M. and Burg, R. 2018. Data base and comparative analysis of CT and transhipment technologies for CT. Available at: https://www.alpine-space.eu/projects/alpinnoct/outputs/deliverable-d.t1.2.1.pdf [Accessed: 2020, October 25].

Li, Y., Liu, X. and Chen, Y. 2011. Selection of Logistics Center Location Using Axiomatic Fuzzy Set and TOPSIS Methodology in Logistics Management. Expert Systems with Applications, 38(6), pp. 7901-7908. Available at: https://doi.org/10.1016/j.eswa.2010.12.161 [Accessed: 2020, October 28].

LOHR. (C) 2016a. Efficient LOHR Railway System (timelapse). Available at: https://lohr.fr/gallery/\#videogallery-1 [Accessed: 2020, October 16].

LOHR. (C) 2016b. Railway system. Available at: https://lohr.fr/lohr-railway-system/ [Accessed: 2020, October 16].

Ministerstvo dopravy. 2018. Koncepce nákladní dopravy pro období 2017-2023 s výhledem do roku 2030. Available at: https://www.mdcr.cz/Dokumenty/Strategie/Koncepce-nakladni-dopravy-pro-obdobi2017-2023-s-v [Accessed: 2020, October 12]. 
Nagel-Group. n.d. Intermodální préeprava - kombinovaná přeprava po Evropě. Available at: https://www.nagel-

group.com/cz/lebensmittellogistik/special services/intermodale verkehre/intermodal traffic kombinie rte verkehre.html [Accessed: 2020, October 19].

Novák, J., Cempírek, V., Novák, I. and Široký, J. 2013. Kombinovaná přeprava. Pardubice: Institut Jana Pernera, o.p.s.

Novák, R., Rathouský, B., Zelený, L., Kolář, P., Pernica, P., Bednarzová, Z., Fišer, V., Havelková, M., Chvátal, P., Ille, J., Medved', J. and Poláček, B. 2018. Mezinárodní silniční nákladní přeprava a zasílatelství. Praha: C. H. Beck.

Perçin, S. 2009. Evaluation of third-party logistics (3PL) providers by using a two-phase AHP and TOPSIS methodology. Benchmarking: An International Journal, 16(5), pp. 588-604. Available at: https://doi.org/10.1108/14635770910987823 [Accessed: 2020, October 27].

Possegger, E. 2012. ISU - Innovativer SattelaufliegerUmschlag Systemübersicht. Available at: https://docplayer.org/42981663-Isu-innovativer-sattelauflieger-umschlag-systemuebersicht.html [Accessed: 2020, October 23].

Rathouský, B., Jirsák, P. and Staněk, M. 2016. Strategie a zdroje SCM. Praha: C. H. Beck.

Široký, J., Cempírek, V. and Gašparík, J. 2012. Transport Technology and Control. Brno: Tribun EU.

Spackman, M., Phillips, L.D. and Pearman, A.D. 2009. Multi-Criteria Analysis: A Manual. Available at: https://www.researchgate.net/publication/30529921_Multi-Criteria_Analysis_A_Manual [Accessed: 2020, October 29].

Stopka, O., Kampf, R., Kolář, J. and Kubasáková, I. 2014. Identification of Appropriate Methods for Allocation Tasks of Logistics Objects in a Certain Area. NAŠE MORE : znanstveni časopis za more i pomorstvo, 61(1-2), pp. 1-6. Available at: https://hrcak.srce.hr/index.php?show=clanak\&id clanak jezik=179818 [Accessed: 2020, October 28].

Stopka, O., Stopková, M. and L'upták, V. 2019. Proposal of the Inventory Management Automatic Identification System in the Manufacturing Enterprise Applying the Multi-criteria Analysis Methods. Open Engineering, 9(1), pp. 397-403. Available at: https://doi.org/10.1515/eng-2019-0046 [Accessed: 2020, October 29].

Todd, S. 2019. Lorry Rail launches Barcelona-Luxembourg shuttle. Available at: https://www.lloydsloadinglist.com/freight-directory/news/Lorry-Rail-launches-BarcelonaLuxembourg-shuttle/73839.htm\#.X6g3HUHA b0 [Accessed: 2020, October 17].

TX Logistik. n.d. The OFFROADER. Available at: https://www.txlogistik.eu/en/services/nikrasa/ [Accessed: 2020, October 19].

UIC. (C) 2020. eNews. Available at: https://uic.org/com/enews/article/belgium-lineas-brings-the-modalshift-to-the-four-country-region-with-a-direct [Accessed: 2020, October 16].

UIRR. 2020. UIRR Annual Report 2019-20. Available at: http://www.uirr.com/en/media-centre/annualreports/annual-reports/mediacentre/1582-uirr-annual-report-2019-20.html [Accessed: 2020, October 12].

UIRR. n.d. Road-Rail CT. Available at: http://www.uirr.com/en/road-rail-ct.html [Accessed: 2020, October 12].

van Leijen, M. 2020. This system can load 50k non-cranable trailers in next 2-3 years. Available at: https://www.railfreight.com/intermodal/2020/06/29/this-system-can-load-50k-non-cranable-trailersin-next-2-3-years/ [Accessed: 2020, October 14]. 
Velasquez, M. and Hester, P.T. 2013. An analysis of multi-criteria decision making methods. International Journal of Operations Research, 10(2), pp. 56-66. Available at:

https://www.researchgate.net/profile/Patrick Hester/publication/275960103 An analysis of multicriteria decision making methods/links/55eefed208ae199d47bff202.pdf [Accessed: 2020, October 28].

VIIA. n.d. Our history. Available at: https://www.viia.com/en/who-are-we/our-history/ [Accessed: 2020, October 16]. 